\title{
Rekrutmen Box Mussel, Septifer bilocularis L. Efek Substratum dan Kepadatan Dewasa
}

\author{
(Recruitment Of The Box Mussel, Septifer bilocularis L.: Effects of Substratum and \\ Adult Density)
}

\author{
Medy Ompi \\ Faculty of Fisheries and Marine Science, Sam Ratulangi University, Manado, 95115, Indonesia \\ Corresponding author: medyompi@yahoo.com
}

Diterima : 1 Juli 2019 Direvisi : 31 Juli 2019 Disetujui : 14 Agustus 2019

\begin{abstract}
An intertidal population of Septifer bilocularis L. was studied in Tongkeina, North Sulawesi, Indonesia. Open and closed cages were applied in field experiments to study the effects of four types of substrata on settling of S. bilocularis: live shells of adults, dead shells, coral rubble, and sand. Each substratum was tested with four levels of adult mussel density: 0, 10, 50, 100 individuals per compartment. The number of recruits as a function of cage, substratum, and adult density was analysed using Two-way ANOVA. The experiment showed that new recruits were affected by the substratum but not by the density of adults. The surface of adult box mussels was the most attractive substratum for recruits

Keywords: coral rubble, population, sand, north Sulawesi, shell

\section{ABSTRAK}

Populasi intertidal Septifer bilocularis L. dipelajari di Tongkeina, Sulawesi Utara, Indonesia. Kandang terbuka dan tertutup diterapkan dalam percobaan lapangan untuk mempelajari pengaruh empat jenis substrat terhadap pengendapan S. bilocularis: cangkang dewasa, cangkang, pecahan karang, dan pasir. Setiap substrat diuji dengan empat tingkat kepadatan kerang dewasa: 0, 10, 50, 100 individu per kompartemen. Jumlah rekrutan sebagai fungsi dari kandang, substratum, dan kepadatan dianalisis menggunakan ANOVA dua arah. Eksperimen menunjukkan bahwa anggota baru dipengaruhi oleh substratum tetapi tidak oleh kepadatan. Permukaan kerang kotak dewasa adalah substrat yang paling menarik untuk direkrut.

Kata kunci: cangkang, pecahan karang, pasir, populasi, substrat, Sulawesi utara
\end{abstract}

\section{PENDAHULUAN}

Rekrutmen didefinisikan sebagai munculnya liur di habitat baru, atau di antara jenis dewasa, setelah tahap larva. Larva planktonik box mussel, Septifer bilocularis L., menghabiskan beberapa minggu (durasi tepatnya tidak diketahui) makan di kolom air. S. bilocularis (Linnaeus, 1758) adalah kerang dari famili Mytilidae kelas Bivalvia yang hidup pada substrat keras, berbatu, atau pada pecahan karang, dan menetap pada daerah karang mat Ketika larva kompeten dan siap untuk menempel, mereka harus menemukan substrat yang sesuai, yang kualitasnya mungkin tergantung pada sifat fisik, biologi, dan kimia (Mohanraj et al., 2013). Metamorfosis dapat terjadi jika larva menemukan substrat yang sesuai, tetapi dapat ditunda jika lingkungan yang sesuai tidak terpenuhi (Ompi et al., 2018). Keberadaan populasi dewasa umumnya menunjukkan substrat yang sesuai yang dapat menyebabkan larva box mussel untuk menetap (Ompi dan Svane, 2018). Namun, pada saat yang sama larva harus menghindari dimakan oleh saringan makan kerang dewasa

Tampalan box mussel, rekrutan baru sebagian besar menempel pada remis dewasa, cangkang mati, dan pecahan karang. Mereka juga ditemukan menempel pada karang mati dan pecahan karang yang ditutupi oleh alga koralin jauh dari dasar kerang dewasa. Penelitian ingin untuk menguji Box mussels tidak memiliki preferensi substrat tertentu dan mengetahui pengaruh kehadiran jenis dewasa pada rekrutmen. 


\section{Lokasi Penelitian}

\section{MATERI DAN METODE}

Eksperimen lapangan dilakukan di sebuah flat intertidal di Tongkeina, Kecamatan Molas, Sulawesi Utara, Indonesia. Percobaan dibiarkan di lapangan selama tiga bulan dari September hingga pertengahan Desember 1996. Dataran tersebut ditutupi oleh karang, karang mati, karang puing, dan pasir.

\section{Desain eksperimental}

Empat jenis substrat yang digunakan dalam percobaan ini meliputi box mussel dewasa dikumpulkan di daerah penelitian dengan memotong secara hati-hati penempelan di usus. Kerang diangkut ke laboratorium ilmu kelautan, dan ditempatkan di akuarium yang diangin-anginkan. Selanjutnya, mereka dikerok, dicuci, dan dikeringkan dengan hati-hati untuk menghilangkan kemungkinan larvanya pada cangkang. Semua kerang diperiksa untuk memastikan bahwa mereka masih hidup. Beberapa kerang diambil bagian lunak dipindahkan, dan kulitnya dijemur selama seminggu. Lubang dibor melalui cangkang. Seutas tali plastik dimasukkan melalui lubang, menghubungkan cangkang menjadi satu, dan kemudian dipasang ke dalam sangkar. (3) Puing karang dan (4) pasir dikumpulkan sekitar $500 \mathrm{~m}$ dari habitat kerang. Puing dan pasir dikeringkan selama satu minggu (di luar ruangan, sinar matahari) sebelum digunakan.

Dua kandang digunakan. Tiap kandang dibagi menjadi 16 kompartemen masing-masing berukuran $15 \times 15$ $x 6 \mathrm{~cm}$. Bagian dasar setiap keramba ditutup dengan jaring plastik ukuran mata jaring $0,5 \mathrm{~mm}$. Substrata memiliki tiga ulangan dan ditempatkan secara acak di dalam kandang. Bagian atas satu keramba ditutup dengan jaring plastik ukuran mata jaring $0,5 \mathrm{~cm}$, sedangkan kandang satunya lagi terbuka. Jarak antara kedua kandang adalah $5 \mathrm{~m}$. Kandang-kandang tersebut ditutup oleh air laut saat air surut. Mereka ditempatkan di tempat yang banyak terdapat box mussels.

Tiga ukuran patch (kepadatan) box mussel diterapkan: patch besar (100 individu), patch sedang (50 individu), dan patch terisolasi (10 individu). Puing karang (tanpa remis) berfungsi sebagai pengendali. Puing-puing tersebut sebelumnya telah digunakan oleh box mussel untuk menempelkan byssus, kecuali yang digunakan di bagian kontrol.

Box mussel dari setiap substrat, kepadatan, dan replikasi dipanen dan disimpan dalam freezer. Selanjutnya permukaan box mussel, cangkang, dan pecahan karang diperiksa menggunakan kaca pembesar dan mikroskop bedah. Pasir diayak (ukuran mata jaring 0,5 dan $1 \mathrm{~mm}$ ) dan diperiksa langsung di bawah mikroskop bedah untuk calon anggota. Rekrut baru dikumpulkan dengan pipet, dihitung, dan disimpan.

\section{Analisis data}

Data jumlah rekrutan sebagai fungsi substrat dan keramba diuji menggunakan ANOVA dua arah. Transformasi akar kuadrat digunakan untuk mendapatkan homogenitas setelah menggunakan uji F-max. Dalam kasus di mana uji ANOVA menunjukkan efek pengobatan yang signifikan, rata-rata dibandingkan dengan menggunakan uji SNK (Sokal \& Rholf, 1981).

\section{HASIL DAN PEMBAHASAN}

ANOVA dua arah, menunjukkan pengaruh yang signifikan dari kandang dan substratum pada perekrutan $(P<0,05)$. Rata-rata kepadatan rekru pada dewasa hidup lebih tinggi dibandingkan pada kerang mati, pecahan karang, dan pasir (uji SNK, $\mathrm{P}<0,05$ ). Kepadatan rata-rata rekrutan pada cangkang dan pecahan karang tidak berbeda nyata (Uji SNK, $P>0,05$ ). Perekrutan secara signifikan lebih rendah pada pasir dibandingkan pada kerang dan puing-puing 3 (uji SNK, $P<0,05$ ) (Gambar 1, 2). 


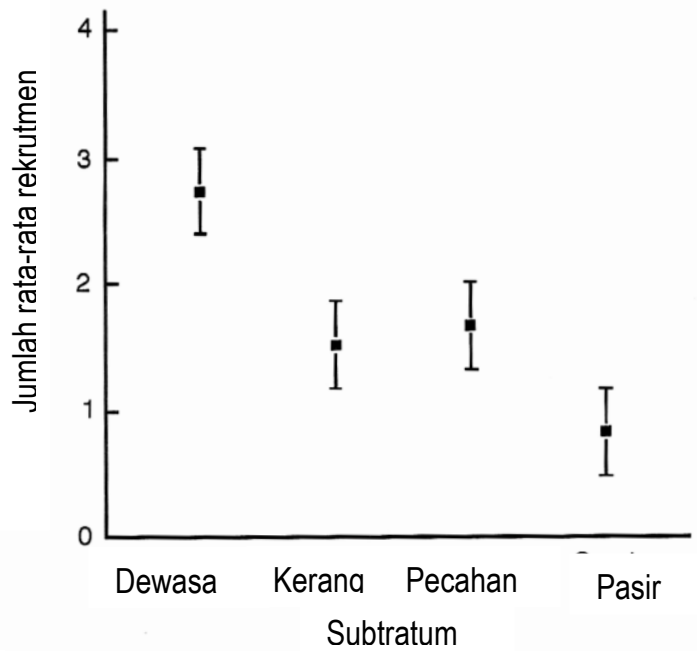

Gambar 1. Jumlah rata-rata rekrutan baru box mussel Septifer bilocularis L. sebagai fungsi substrat. (Batang: confidence interval 95\%).

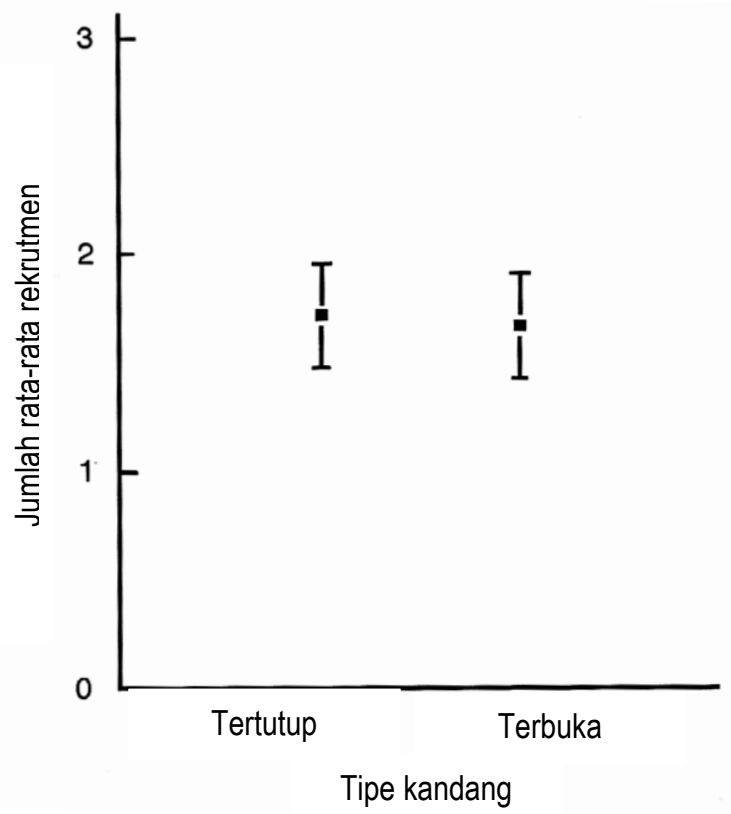

Gambar 2. Jumlah rata-rata rekrut baru box mussel Septifer bilocularis L. di kandang tertutup dan terbuka. (Batang: confidence interval 95\%).

Sejumlah besar rekrutmen ditemukan menempel pada orang dewasa di kandang tertutup dan terbuka (Gambar 3, 4). 


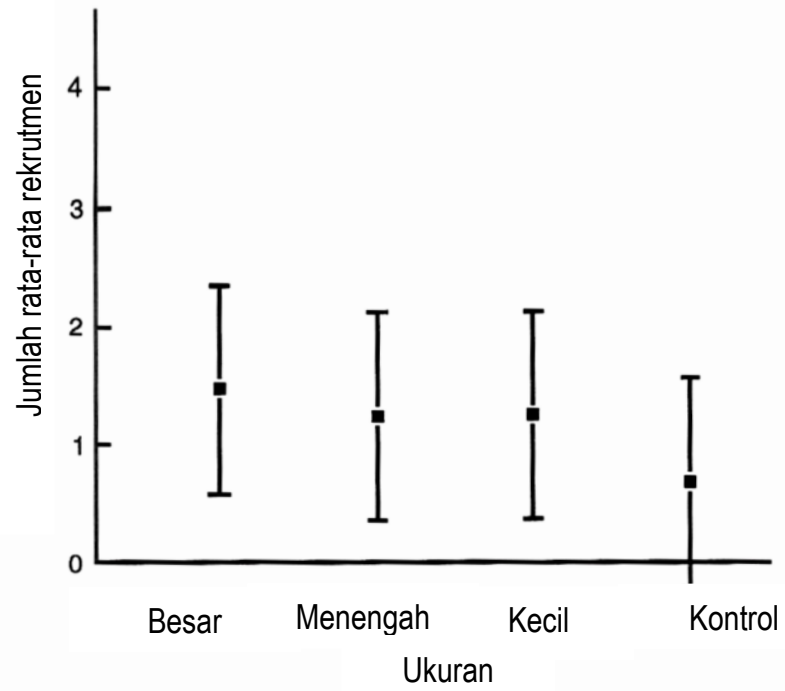

Gambar 3. Jumlah rata-rata rekrutan baru box mussel Septifer bilocularis L. sebagai fungsi dari kepadatan remis dewasa di kandang terbuka. Kontrol: Puing karang tetapi tidak terdapat box mussel. (Batang: confidence interval 95\%).

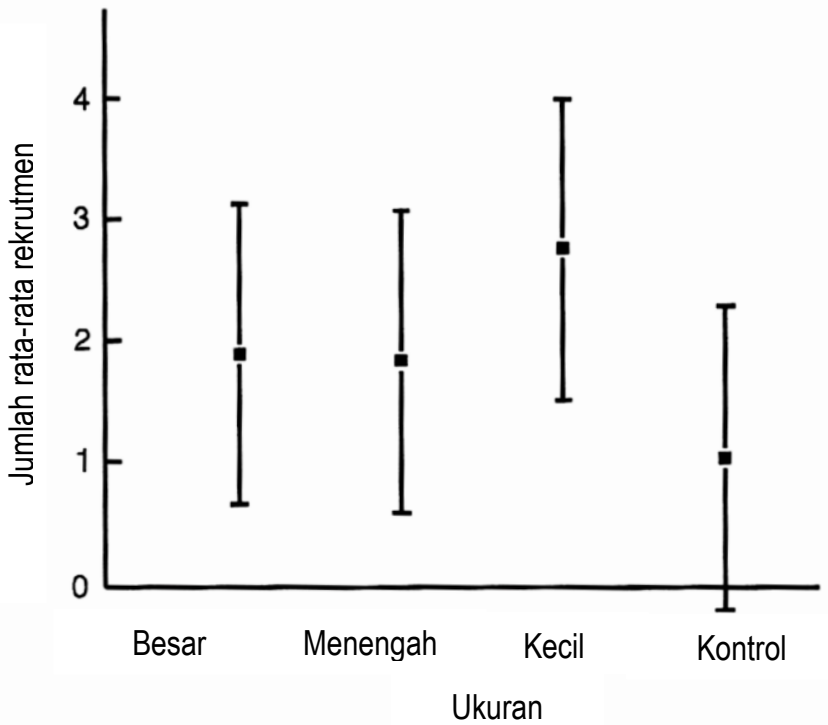

Gambar 4. Jumlah rata-rata rekrutan baru box mussel Septifer bilocularis L. sebagai fungsi dari kepadatan remis dewasa di kandang tertutup jaring. Kontrol: Puing karang tetapi tidak terdapat box mussel. (Batang: confidence interval 95\%).

Permukaan box mussel dewasa merupakan substrat yang paling menarik untuk direkrut dibandingkan dengan cangkang mati, pecahan karang, dan pasir (Mohanraj et al., 2013). Hewan laut diketahui melepaskan isyarat kimiawi yang dapat menyebabkan larva menetap atau menghalangi mereka melakukannya. Box mussel dewasa kemungkinan besar melepaskan senyawa yang menyebabkan larva kompeten untuk menetap, seperti yang ditemukan di Mercenaria mercenaria. Kerang ini menetap dalam jumlah yang lebih tinggi pada substrat yang diberi ekstrak kerang dibandingkan dengan substrat yang tidak diberi perlakuan. Secara umum, pasir memiliki mikroflora dan fauna yang berkembang dengan baik yang dapat menyebabkan larva avertebrata menetap dan bermetamorfosis (Mustamu et al., 2014). Namun, pasir juga merupakan substrat yang tidak stabil yang dapat menghambat pembentukan box mussel remaja.

Pengumpan suspensi dewasa dapat menyebabkan larva untuk menetap, tetapi ada juga risiko tersedot ke dalam siphon inhalan, berakhir sebagai mangsa. Penurunan jumlah rekrutan pengumpan suspensi dengan meningkatnya jumlah jenis dewasa. Bagaimanapun, dalam penelitian ini tidak ada indikasi pengaruh kepadatan jenis dewasa pada rekrutmen. Pengendapan larva remis tidak dipengaruhi oleh kepadatan larva kerang dewasa. 
Ini mungkin terkait dengan perilaku box mussel dewasa. Bagian bawah kompartemen percobaan ditutupi kerang secara seragam. Tapi kemudian, kerang menggumpal di sepanjang tepi dan ada ruang kosong di antara rumpun di setiap kandang.

Dalam studi ini, rekrutan juga ditemukan pada cangkang mati dan pecahan karang yang sebelumnya pernah ditempeli kerang dewasa. Hal ini menunjukkan bahwa larva mungkin menjaga jarak dari kerang dewasa saat mereka menetap. Mengenai predator, kepiting diketahui memangsa box mussel. tetapi juga organisme bentik lainnya, misalnya echinoid dan bintang laut mungkin memangsa organisme sesil kecil. Echinoid dan bintang laut selalu ditemukan di kandang terbuka dan mungkin memakan beberapa rekrutan.

Penempelan sekunder telah dijelaskan untuk Mytilus edulis dan diketahui sudah umum di famili Mytilidae. Larva M. edulis pada awalnya harus menetap di alga berserabut (penempelan primer). Rekrutmen ke dasar remis dewasa diikuti setelah periode pertumbuhan dan melibatkan fase kedua. Penempelan dapat dipengaruhi oleh faktor kematian (Ompi, 2010). Penempelan langsung larva di dasar remis dewasa M. edulis dan M. californianus . Tidak diketahui apakah penempelan sekunder terjadi pada box mussel seperti yang ditemukan di Mytilus edulis.

Selain itu, $M$. virgata mempunyai daya tahan terhadap tekanan suhu tinggi dan paparan udara daripada M. edulis, serta habitat yang sesuai (Carl et al., 2012). $\mathrm{pCO}_{2}$ tinggi mempengaruhi ukuran tubuh, tetapi tidak pada ekspresi gen pada larva kerang (M. californianus) (Kelly et al., 2014)

\section{KESIMPULAN}

Jumlah rekrutan yang lebih tinggi yang diamati di kandang tertutup dibandingkan dengan kandang terbuka mungkin disebabkan oleh jaring itu sendiri, tetapi juga oleh keluarnya predator.

\section{UCAPAN TERIMA KASIH}

Saya ingin mengucapkan terima kasih kepada Dr. Lucky Lumingas, Dr. Yanny Kusen, dan Ir. Benny Pratasik, MSc, Fakultas Perikanan dan IImu Kelautan, Manado atas pembacaan naskah. Terima kasih kepada Dr. Gudrun Thorarinsdottir, Institut Penelitian Kelautan, Islandia untuk diskusi dan literaturnya. Terima kasih juga untuk Ir. Frans Lumoindong, Stevly Modaso, dan Alianto Mahmud atas bantuan pekerjaan lapangan. Studi ini didukung oleh TMMP melalui DANIDA, Denmark.

\section{DAFTAR PUSTAKA}

Carl, C., Poole, A. J., Williams, M. R., de Nys, R. (2012). Where to Settle-Settlement Preferences of Mytilus galloprovincialis and Choice of Habitat at a Micro Spatial Scale. PLOS ONE, 7(12):. https://doi.org/10.1371/journal.pone.0052358

Kelly, M. W., Padilla-Gamiñ, J. L., Hofmann, G. E. (2014). High pCO2 affects body size, but not gene expression in larvae of the California mussel (Mytilus californianus). Encyclopedia of Environment and Society, 73:962969. https://doi.org/10.4135/9781412953924.n678

Mohanraj, T., Jagadis, I., Sivanesh, H. (2013). Association of molluscan fauna with the coral reefs of Gulf of Mannar. European Journal of Experimental Biology, 1(3):44-48.

Mustamu, G., Lumingas, L. J., Lohoo, A. V. (2014). Kepadatan, pola sebaran, dan morfometrik kerang kotak Septifer bilocularis (Linnaeus, 1758) pada rataan terumbu di Tanjung lampangi, Minahasa selatan. Jurnal IImiah Platax, 2(1):8-18.

Ompi, M. (2010). Settlement Behaviour and Size of Mussel Larvae From the Family Mytilidae. Journal of Coastal Development, 13(3):215-227.

Ompi, M., Lomoindong, F., Mandagi, S. V. (2018). Effects of artificial and natural materials ropes as substrates for settling and metamorphosis of pediveliger pearl oyster, Pinctada maxima (Jameson, 1901). AACL Bioflux, 11(3):796-803. https://doi.org/10.1088/1755-1315/162/1/012031

Ompi, M., Svane, I. (2018). Comparing spawning, larval development, and recruitments of four mussel species (Bivalvia: Mytilidae) from south australia. AACL Bioflux, 11(3):576-588. 